\title{
Taxonomic study of the genus Epiphragma of Japan (Diptera: Limoniidae)
}

\author{
Daichi KATO ${ }^{1,2, *)}$, Takeyuki NAKAMURA ${ }^{3)} \&$ Takuji TACHI ${ }^{2)}$ \\ ${ }^{1)}$ Echigo-Matsunoyama Museum of Natural Sicences, 'Kyororo', 1712-2 Matsunoyama, Tôkamachi, 942-1411, Japan \\ ${ }^{2)}$ Biosystematics Laboratory, Faculty of Social and Cultural Studies, Kyushu University, 744 Motooka, Fukuoka 819-0395, Japan; \\ e-mail: hehemanpuldoa.d4@gmail.com \\ 3) The Shirakami Institute for Environmental Sciences, Hirosaki University, Bunkyo-cho 3, Hirosaki City, Aomori 036-8561, Japan \\ *) corresponding author
}

Accepted:

$22^{\text {nd }}$ July 2020

Published online:

$1^{\text {st }}$ August 2020

\begin{abstract}
Japanese species of the genus Epiphragma Osten Sacken, 1860 are revised. Epiphragma amamiense sp. nov. is described, and E. gracilistylus Alexander, 1933 and E. kempi Brunetti, 1913 are recorded from Japan for the first time. It is revealed that records of $E$. evanescens Alexander, 1940 from Japan were based on misidentifications of E. gracilistylus and E. trichomerum Alexander, 1955. Therefore, a total of six species are recognized from Japan, and the previous records which based on misidentifications are corrected. Male and female terminalia of these six species are illustrated and a key to these species is provided.
\end{abstract}

Key words. Diptera, Tipuloidea, Limoniidae, Limnophilinae, Epiphragma, crane fly, new species, new record, Japan, Palaearctic Region

Zoobank: http://zoobank.org/urn:lsid:zoobank.org:pub:5CF7D8D7-2AEF-4AFB-9DB2-80A8FB525144

(C) 2020 The Authors. This work is licensed under the Creative Commons Attribution-NonCommercial-NoDerivs 3.0 Licence.

\section{Introduction}

Epiphragma Osten Sacken, 1860 is one of the genera belonging to the subfamily Limnophilinae. This genus was first established as a subgenus of Limnophila Marcquart, 1834 and was subsequently raised to a genus by OsTEN SACKen (1869). Epiphragma is distinguished from the other genera by having wings with supernumerary crossvein(s) in cell c and peculiar spotted and banded markings. It consists of four subgenera, Epiphragma (widespread except for the Afrotropical Region, 115 species), Eupolyphragma Alexander, 1948 (the Oriental and Australian Regions, 25 species), Lipophragma Alexander, 1978 (the Australian Region, 1 species), and Parepiphragma Alexander, 1960 (the Australian Region, 1 species) with one Indonesian species whose subgeneric position is uncertain (OOSTERBROEK 2019). In temperate regions, adults of the genus inhabit forests and appear from spring to summer. They are often observed resting on the upper surface of leaves or fallen trees keeping their wings outspread horizontally. The male flies swarm in the evening before sunset. The larvae and pupae inhabit moist decaying wood (AlEXANDER 1920, 1948, Krivosheina 2009).
In Japan, four species of Epiphragma have been recorded: E. evanescens Alexander, 1940, E. subfascipenne Alexander, 1920, E. subinsigne Alexander, 1920, and E. trichomerum Alexander, 1955. All Japanese species belong to the subgenus Epiphragma.

Despite the importance of wing markings in the taxonomy of the group, all Japanese species of Epiphragma were described without illustrations of these markings. Moreover, the male genitalia of the species other than E. trichomerum have not been illustrated in the original descriptions. Although Epiphragma species were figured in some Japanese literature (E. subfascipenne and E. subinsig$n e$ in ESAKI (1932), E. evanescens and E. trichomerum in TAKAHASHI (1965) and NaKAMURA (2008), E. evanescens in KINOTA (2006) etc.), the identifications were uncertain for the above-mentioned reasons.

In this study, we investigate the type specimens of regional Epiphragma species preserved in the National Museum of Natural History, Washington D. C., specimens from various localities in Japan, and we clarify the Japanese species of the genus. 


\section{Materials and methods}

Most specimens used in this study were collected in the field by the authors using insect nets and Malaise traps (MT). Specimens were examined in dry condition. The genitalia were observed in glycerol after being boiled in a solution of $10 \% \mathrm{KOH}$ and then rinsed in a solution of $70 \%$ ethanol with $3 \%$ acetic acid for neutralization. The treated genitalia were preserved in genitalic tubes filled with glycerol and the tubes were pinned with their bodies. Wings were photographed from slides mounted in Euparal. Terminology follows mainly that of CumMING \& Wood (2017).

The following acronyms of museums and collections are used in this paper:

BLKU Biosystematics Laboratory, Kyushu University, Fukuoka, Japan; ELEU Entomological Laboratory of Ehime University, Matsuyama, Japan;

ELKU Entomological Laboratory of Kyushu University, Fukuoka, Japan;

SIHU Shirakami Institute for Environmental Sciences, Hirosaki University, Hirosaki, Japan;

USNM National Museum of Natural History, Smithsonian Institution, Washington, D.C., USA.

\section{Taxonomy}

\section{Genus Epiphragma Osten Sacken, 1860}

Epiphragma Osten Sacken, 1860: 238 (as subgenus of Limnophila Macquart, 1834). Type species: Limnophila pavonina Osten Sacken, 1860.

Epiphragma: Osten SACKEN (1869): 193 (elevated to genus).

Remarks. In the Japanese species, the following characters are shared: medium sized, brownish flies; head with vertex bearing indistinct dark markings or longitudinal line; eye dichoptic in both sexes; antenna relatively long, if bent backward, reaching near base of halter, scape cylindrical, flagellum with 13 segments, first two flagellomeres fused or partly so; thorax with prescutum bearing three or four indistinct darker stripes, pleuron variegated with darker areas and pruinescence; legs yellowish brown; each femur with one or two brown bands; fore tibia with one, succeeding tibiae with two apical spurs; wing with characteristic brownish pattern, forming several circular markings in line, tips of all longitudinal veins, crossvein $h$, and supernumerary crossvein in cell $\mathrm{c}$ with brown spots; Rs long, distal part parallel with $\mathrm{R}_{1}$; crossvein $\mathrm{r}-\mathrm{r}$ situated about its length before tip of $\mathrm{R}_{1}$; MA absent; cell d closed; cell $\mathrm{m}_{1}$ present; $\mathrm{m}$-cu at basal 1/6-1/2 of cell d; male genitalia with tergite 9 produced into pair of small lobes at posterior margin; outer gonostylus claw-shaped, tip sharply tapered and curved inward; inner gonostylus slightly longer than outer gonostylus, obtuse at tip, slightly curved inward; interbase prominent, rod extending posteriorly; female ovipositor with cercus shorter than tergite 10, curved upwards; hypogynial valve relatively short, subequal in length to sternite 8 ; sternite 8 with linear apodeme on lateral side.

\section{Key to the Japanese species of Epiphragma}

1 Wing marking on outer end of cell $d$ solid, without subhyaline areas, center of cell d broadly subhyaline (Figs 17, 31).
- Wing markings on inner and outer ends of cell d with subhyaline areas, center of cell d with brownish marking (Figs 2, 9, 24, 38).

2 Each femur usually with two bands distally; mediotergite without $\mathrm{V}$-shaped lighter area; male genitalia with interbase slender, bearing several teeth near tip (Fig. 33); female ovipositor with sternite 8 bearing linear apodeme on its entire length (Fig. 34).

E. subinsigne Alexander, 1920

- Each femur with one brown band near tip; mediotergite with V-shaped lighter area; male genitalia with interbase somewhat stout, curved medially and flattened near tip (Fig. 19); female ovipositor with sternite 8 bearing linear apodeme on posterior half (Fig. 20). .....

E. kempi Brunetti, 1913

3 Each femur usually with two bands distally; male genitalia with interbase stout on base, rod shorter than base (Fig. 11); female ovipositor with furca slender Y-shaped (Fig. 13)

E. gracilistylus Alexander, 1933

- Each femur with one brown band near tip; male genitalia and female ovipositor not as above. ...................... 4

4 Femoral band at tip or almost so; wing markings distinctly outlined with darker margins (Fig. 24); halter entirely light yellow; male genitalia with interbase long and straight (Fig. 26), extending beyond tip of aedeagus (Fig. 25); female ovipositor with sternite 8 bearing linear apodeme in whole length (Fig. 27).

E. subfascipenne Alexander, 1920

- Femoral band subapical; wing markings bordered with darker margins on anterior half of wing or without darker margins (Figs 2, 38); halter darkened at base of knob; male genitalia with interbase not as above. ...... 5

5 Circular marking enclosing base of Rs with distinct marking inside, cell d with three subhyaline spots (Fig. 38); male genitalia with interbase S-curved (Fig. 40); female ovipositor with furca strongly widened and membranous on anterior part (Fig. 42).

E. trichomerum Alexander, 1955

- Circular marking enclosing base of Rs with narrow seam inside, restricted at base of Rs, cell d with two subhyaline spots (Fig. 2); male genitalia with interbase L-shaped (Fig. 4); female ovipositor with furca narrowed and sclerotized on anterior part (Fig. 6).

E. amamiense sp. nov.

\section{Epiphragma (Epiphragma) amamiense sp. nov. \\ (Figs 1-7, 45)}

Type material. Holotype: (BLKU), JAPAN: NANSEI IsLANDS: Amami Islands: Kagoshima: Amami Island, Setouchi-chô, Mt. Eboshi, Shinokawa, 3.x.2013, D. Kato (pinned, one hindleg missing). PARATYPES

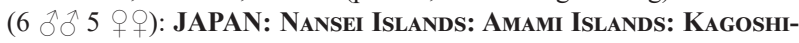
MA: 2 o 1 , Amami Island, Setouchi-chô, Mt. Eboshi, Shinokawa, 3.x.2013, D. Kato (BLKU); 1 \ 1 , Amami Island, Setouchi-chô, Mt. Yui-dake, 5.vii.2007, H. Makihara (BLKU); $3 \hat{\delta} 2$ 우, Tokunoshima Island, Tokunoshima-chô, Kedoku, Mt. Minada-yama, 30.ix.2013, D. Kato (BLKU); 1 + , Tokunoshima Island, Amagi-chô, Mikyo Path, 29.iv.1996, R. Matsumoto (SIHU).

Description. Male. Body length 7.8-9.7 mm. Wing length $8.0-9.1 \mathrm{~mm}$. 


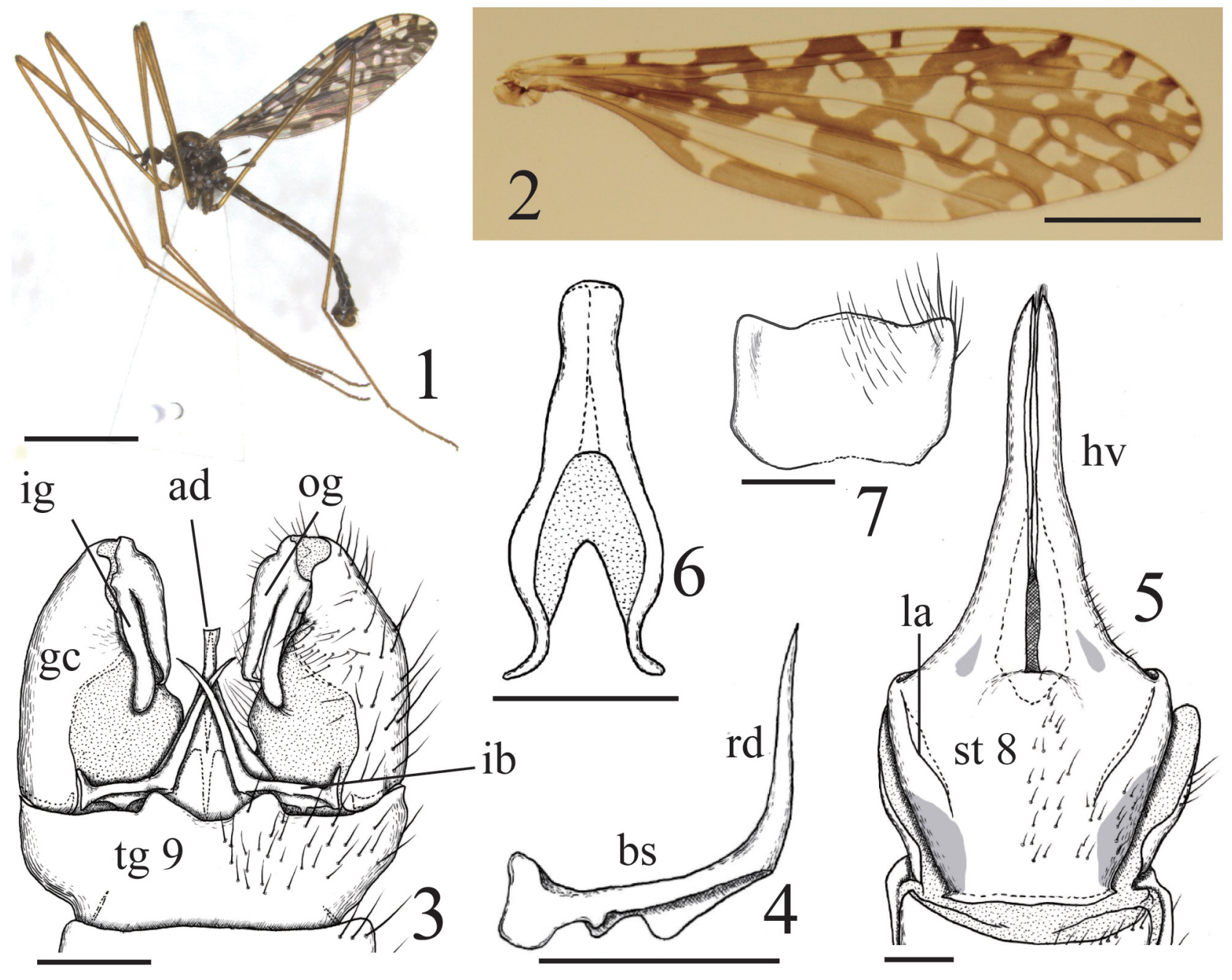

Figs 1-7. Epiphragma amamiense sp. nov. 1 - habitus (male); 2 - wing; 3 - male genitalia in dorsal view; 4 -interbase in dorsal view; 5 - female abdominal sternite 8 and hypogynial valve in ventral view; 6 - furca in dorsal view (upper side direct anteriorly); 7 - female abdominal sternite 10 in ventral view (upper side directs posteriorly). Abbreviations: ad, aedeagus; bs, base of interbase; gc, gonocoxite; hv, hypogynial valve; ib, interbase; ig, inner gonostylus; la, linear apodeme; og, outer gonostylus; rd, rod of interbase; st 8, sternite 8; tg 9, tergite 9. Scale bars = 5 mm (1), $2 \mathrm{~mm}(2), 0.25 \mathrm{~mm}(3-7)$.

Head brown to dark brown with yellowish grey pruinescence; vertex widely darkened along central line, especially at middle; antenna with scape and pedicel dark brown, pedicel sometimes slightly yellowish; flagellomeres 1-2 orange-yellow, subsequent flagellomeres evenly darkened; palpus and mouth parts dark brown.

Thorax with mesonotum brown to dark brown, anterior end of mesonotum with darker area extending posteriorly and often narrowed into capillary line; lateral sides of prescutum darker, these dark areas extending posteromedially; pruinescence on mesonotum grey and weak, indistinct on anterior half and lateral sides in dorsal view; prescutum with four darker areas on posterior half, sometimes fused to one another; postsutural area largely darkened at middle, outer anterior edge of scutal lobe with small dark spot; scutellum dark brown; mediotergite dark brown with indistinctly paler band at middle; pleuron brown to dark brown variegated with darker areas and pruinescence. Legs with coxae and trochanters yellowish brown, fore coxa with dark area at middle, mid and hind coxae with dark area on lower half; femora, tibiae and tarsi yellow to yellowish brown, each femur with brown band near tip, 0.8-1.0 times as long as width of femur in specimens from Amami Is. and 3.2-4.0 times in those from Tokunoshima Is.; distal segments of tarsomeres slightly darker. Wing (Fig. 2) 3.7-4.5 times as long as wide, greyish subhyaline with dark brown markings, evenly darkened on costal regions, markings on other areas sometimes with darker margin; four adjacent circular markings present anterior to $\mathrm{CuA}$, second circle enclosing origin of Rs, third circle enclosing around cord, fourth circle enclosing outer end of cell d, first and fourth circles smaller, markings inside second and third circles restricted on veins; cell sc often with small subhyaline spot at distal end; cell d with two subhyaline areas on inner and outer sides; spots at tips of veins near wing tip usually fused at bases with adjacent ones, except for one at tip of $\mathrm{R}_{2}$; variation of development of wing marking small in same locality. Halter dark brown, apex of knob and base of stem yellowish.

Abdomen brown, lateral margins of tergites and sternites darker, posterior margin of each segment paler with weak grey pruinescence, widened laterally on tergites; abdominal 
segments 5-8 darkened, sternites 1-4 paler than tergites 1-4. Male genitalia (Fig. 3) with tergite 9 bearing pair of rounded median lobes at posterior margin, bases of lobes somewhat separated; sternite 9 flattened at caudal margin, without conical tubercle; gonocoxite paler brown; gonostyli large, about $1 / 2$ length of gonocoxite; interbase (Fig. 4) with rod short, not reaching distal end of aedeagus, slightly curved dorsally in whole length, tapered toward tip; base of interbase about as long as rod.

Female. Body length 8.7-11.0 mm. Wing length 8.0-9.1 $\mathrm{mm}$. Generally resembling male except for terminalia.

Ovipositor with sternite 8 (Fig. 5) bearing linear apodeme on lateral side of posterior half; when viewed ventrally, sternite 8 excluding hypogynial valve usually slightly shorter than wide, with dark markings on anterior half of lateral margin, and with pair of bacilliform dark markings near base of hypogynial valve, about twice as long as wide in specimens from Amami Is. and more than four times in those from Tokunoshima Is.; furca (Fig. 6) forked near middle, widest at sinuous posterior part, anterior plate slightly narrowed toward and rounded at anterior end, in specimens from Tokunoshima Is. anterior part wider and weakly sclerotized on lateral part; sternite 10 (Fig. 7) largely roughly squarish, weakly trilobed at posterior margin, middle lobe wider than lateral ones.

Etymology. This species is named after the type locality, Amami Islands; adjective.

Distribution. Japan, Nansei Islands, Amami Islands (Fig. 45).

Remarks. This new species is somewhat similar to Epiphragma mediale Mao \& Yang, 2009 from China in regard to wing markings and the shape of male genitalia, but is differentiated from them by the following characters: each femur with one short band (two bands in E. mediale); male genitalia with rod of interbase almost straight in whole length (bent near tip in E. mediale).

\section{Epiphragma (Epiphragma) gracilistylus Alexander, 1933 \\ (Figs 8-14, 44)}

Epiphragma ocellaris gracilistylus Alexander, 1933: 141. Type locality: Russian Far East, Primorskiy kray, Suchan district.

Epiphragma evanescens (misidentified, non Alexander, 1940): KINOTA (2006: 182)

Epiphragma ocellare gracilistylus: SAVCHENKO et al. (1992: 215).

Epiphragma (Epiphragma) gracilistylus: OOSTERBROEK (2019).

Type material examined. HoLOTYPE: $\widehat{\jmath}$ (USNM), RUSSIA: SUCHAN DISTRICT: Tigrowaja, 16.VI.1927, Stackelberg.

Non-type material examined. JAPAN: HoKKAIDO: $2 \propto q$, Bifuka-chô, Niupu (MT), 19.vi-17.vii.2010, M. Kuhara \& M. Sueyoshi (SIHU); 1 , Rumoi-shi (MT), 1-15.vii.2011, Y. Nagayasu (SIHU); 1 , Kamikawa -chô, Ginsendai (MT), 27.vi-18.vii.2008, A. Ueda (SIHU); 2 4 + 9 , Kuriyama-chô (MT), 22.vi-12.vii.2006, A. Ueda (SIHU); 1 + , Sapporo -shi, Minami-ku, Jôzankei, Climb of Mt. Sapporo-dake, 23.vi.2014, D. Kato (BLKU); 1 , Sapporo-shi, Hitsujigaoka (MT), 29.v-5.vi.2009, K. Konishi (SIHU); 1 , Chitose-shi, Bifue, Kusabue-rindo (MT), 21.vi-8. vii.2012, N. Kuhara (SIHU); 2 ô 1 , Yûbari-shi, Momijiyama (MT), 4-25.vi.2008, A. Ueda (SIHU); 2 $\hat{\jmath} 1$ क , Furano-shi, Nishitappu (MT), 5-26.vi.2009, A. Ueda (SIHU); 8 o 2 우, Minamifurano-chô, Ikutora (MT), 5-25.vi.2009, A. Ueda (SIHU); 1 के, same data as previous except 1-8.vi.2010; 1 9, Tomakomai-shi, Hokkaido Univ. Exp. Forest (MT), 2-3.vii.2009, T. Yoshida (SIHU); 4 + + , Ashoro-chô, (MT), 26.vi-17. vii.2008, A. Ueda (SIHU); 2 †+, Shari-chô, Nukamappu-gawa River (MT), 30.v-13.vii.2001, K. Uesugi (SIHU); 4 우, Teshikaga-chô (MT), 5-26.vi.2008, A. Ueda (SIHU); 1 , Kushiro-shi, Senpo-ji (M. T.), 17.vi-23.vii.2002, K. Uesugi (SIHU). Honshu: 1 \%, Aomori, Hirosaki-shi, Inekari-zawa River, 3.vi.2010, T. Nakamura (SIHU); 2 ㅎํ, Aomori, Nishimeya-mura, 24.vi.2012, D. Kato (BLKU); 1 \%, Fukushima, Hinoemata-mura, 11.vi.1995, T. Nakamura (SIHU); 1 ô, Tochigi, Shiobara-machi, Shionoyu Spa, 14.vi.1999, T. Nakamura (SIHU); 1 ô, Yamanashi, Kôshu-shi, Enzankamihagihara, Kaminichikawa-tôge Pass, 8.vii.2014, D. Kato (BLKU); 2 ơ 2 우, Niigata, Myôkôkôgen-machi, Sasagamine, 28.vi.1999, T. Nakamura (SIHU); $1 \hat{~} 1$, Nagano, Togakushi-mura, 27.vi.1996, T. Nakamura (SIHU); 1 , Okayama, Maniwa-shi, Hiruzen-Shimotokuyama, 17.v.2015, D. Kato (BLKU). SнгкокU: 1 , Iуо (Ehime), Mt. Ishizuchi, 9.vi.1950, Issiki-Ito (identified by Alexander as E. evanescens Alexander, 1940 / USNM). KyUSHU: 1 ô, Kumamoto, Yatsushiro-shi, Haki, 23.v.1997, T. Nakamura (SIHU). RUSSIA: Far EAST: 4 ô, Primorsky Krai, Kedrovaya Pad Reserve, 2.vi.1992, T. Nakamura (SIHU).

Redescription. Male. Body length 8.3-12.4 mm. Wing length 9.8-12.3 $\mathrm{mm}$.

Head orange to brown with grey pruinescence; vertex darkened along central line, this dark area widened at middle; antenna with scape and pedicel dark brown to brown, pedicel sometimes slightly yellowish; flagellomeres 1-2 orange-yellow, following flagellomeres slightly darkened toward antennal end; palpus and mouth parts dark brown.

Thorax with mesonotum brown to dark brown, anterior end and lateral sides darker, with strong grey pruinescence, indistinct on anterior and lateral margins in dorsal view; prescutum with four weakly darker stripes, central pair more slender and longer, extending anteriorly beyond level of prescutal pit, lateral stripes extending from near level of prescutal pit to scutellum, narrowly interrupted obliquely on scutal lobe, interspace between scutal lobes near posterior end with pair of dark areas, sometimes fused and extending to basal area of scutellum; mediotergite brown to dark brown; pleuron light brown to brown, variegated with darker areas and strong pruinescence. Legs with coxae and trochanters yellow to brown; femora, tibiae and tarsomeres 1-2 yellow to yellowish brown, following tarsomeres sometimes darkened; each femur with two brown bands, distal one long, situated at tip, usually 3-5 times as long as width of femur, sometimes weakened at tip, basal one shorter, situated at basal 3/4 of femur, sometimes indistinct. Wing (Fig. 9) 3.5-4.1 times as long as wide, greyish subhyaline with brown markings, slightly outlined with dark brown; markings interrupted transversely at basal 1/2 and 3/4 of wing, each section of markings sometimes fused partly; circular marking enclosing base of Rs with distinct marking inside; both sides of inner and outer ends of cell $\mathrm{d}$ with small subhyaline areas; cell $\mathrm{d}$ with two or three subhyaline areas; cell sc usually with small subhyaline area at distal end; spots at tips of veins near wing tip fused at bases with adjacent ones; variation of development of wing marking large in specimens from the same locality. Halter yellow with dark band at base of knob.

Abdomen brown to dark brown, distal segments darker, with weak grey pruinescence, denser along posterior margin of each segment; tergites with central longitudinal dark line, sometimes indistinct; sternites slightly paler than tergites, each segment darkened along lateral margins. 

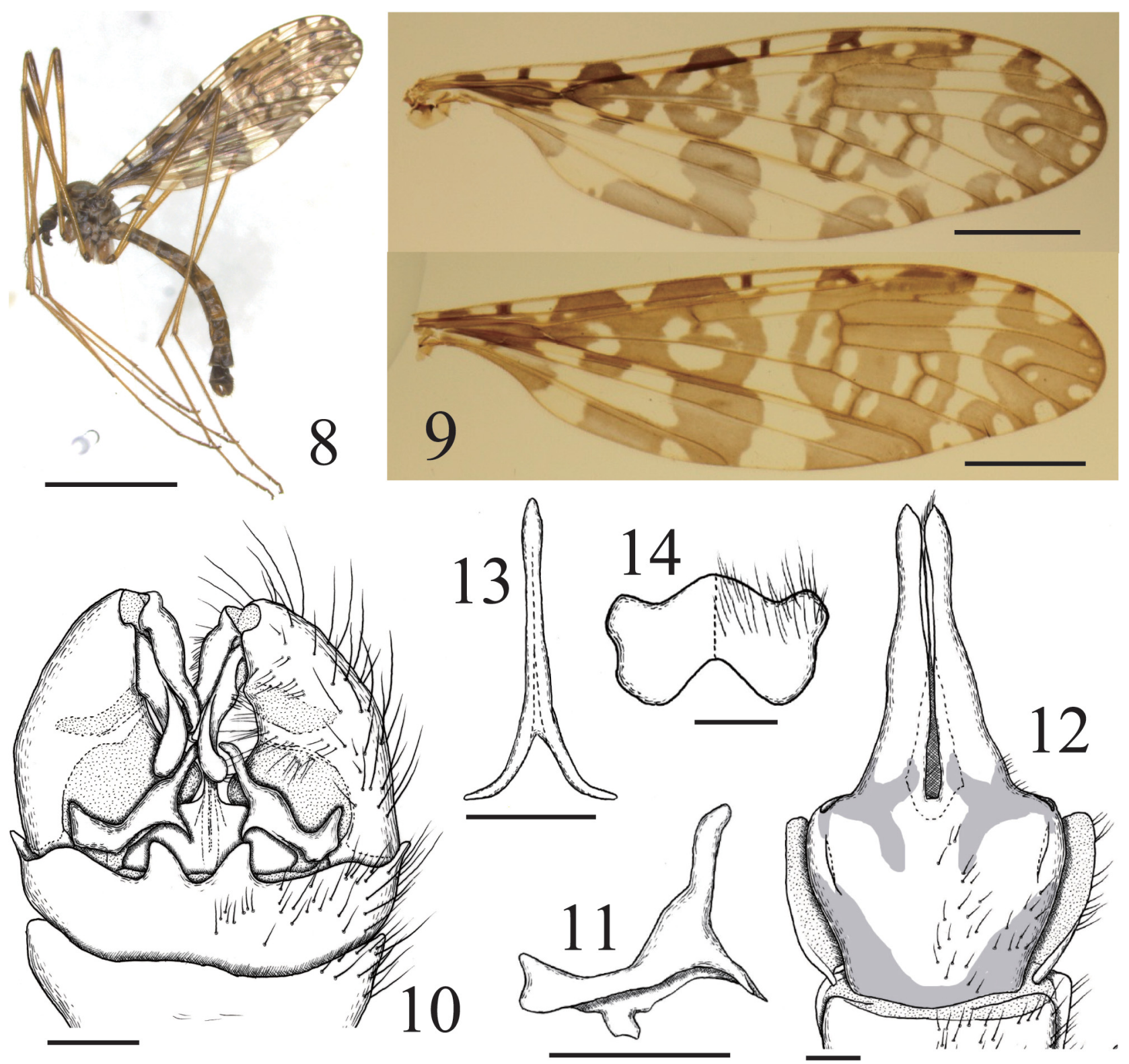

Figs 8-14. Epiphragma gracilistylus Alexander, 1933. 8 - habitus (male); 9 - wings (upper one with less developed wing marking, lower one with well-developed wing marking); 10 - male genitalia in dorsal view; 11 - interbase in dorsal view; 12 - female abdominal sternite 8 and hypogynial valve in ventral view; 13 - furca in dorsal view; 14 - female abdominal sternite 10 in ventral view. Scale bars $=5 \mathrm{~mm}(8), 2 \mathrm{~mm}(9), 0.25 \mathrm{~mm}(10-14)$.

Male genitalia (Fig. 10) with tergite 9 bearing pair of large subtriangular median lobes at posterior margin; sternite 9 flattened at caudal margin, without tubercle; gonostyli large, about 1/2 as long as gonocoxite; interbase (Figs 11) with rod short, tip ending before tip of aedeagus; base of interbase stout and longer than rod.

Female. Body length 11.1-14.6 mm. Wing length 11.8$13.3 \mathrm{~mm}$. Generally resembling male except for terminalia.

Ovipositor with sternite 8 (Fig. 12) bearing linear apodeme on lateral side of posterior half; when viewed ventrally, length of sternite 8 excluding hypogynial valve usually slightly shorter than wide, with pair of distinct dark markings between linear apodemes, these dark areas connecting with dark areas on lateral sides of base of hypogynial valve, other large dark markings present in anterior corners of sternite 8 , markings sometimes weake- ned variously; furca (Fig. 13) slender Y-shaped, forked at posterior 1/4; sternite 10 (Fig. 14) with two rounded lobes separated by large notch at anterior end and three lobes on posterior end, middle one wider than lateral ones.

Distribution. Japan (Hokkaido; Honshu; Shikoku; Kyushu) (Fig. 44), Russia (Far East), and China (Zhejiang). First record of this species in Japan.

\section{Epiphragma (Epiphragma) kempi Brunetti, 1913} (Figs 15-22, 46)

Epiphragma kempi Brunetti, 1913: 155. Type locality: India, Assam, between Kalek and Misshing.

Epiphragma kempi: EDWARDS (1913: 204).

Epiphragma (Epiphragma) kempi: OOSTERBROEK (2019).

Non-type material examined. JAPAN: NANSEI ISLANDS: AMAMI IsLANDS: $2 \uparrow q$, Kagoshima, Amami Island, Setouchi-chô, Mt. Yui-dake (MT), 10.viii.2004, H. Makihara (SIHU); 1 , Kagoshima, Amami Island, 

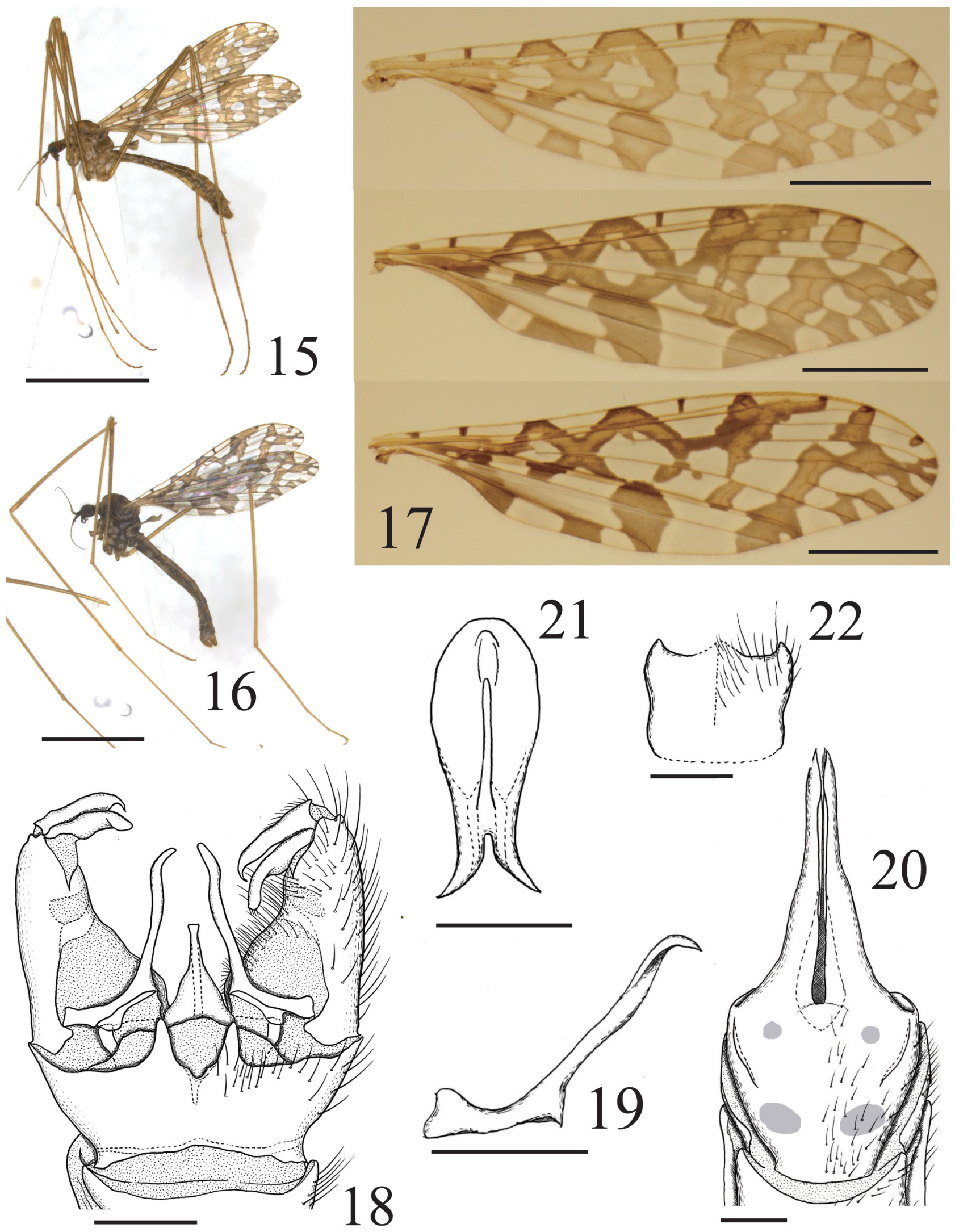

Figs 15-22. Epiphragma kempi Brunetti, 1913. 15 - habitus (male from Tokunoshima Is.); 16 - habitus (male from Ishigaki Is.); 17 - wings (upper one from Amami Is., middle one from Okinawa Is., lower one from Ishigaki Is.); 18 - male genitalia in dorsal view; 19 - interbase in dorsal view; 20 - female abdominal sternite 8 and hypogynial valve in ventral view; 21 - furca in dorsal view; 22 - female abdominal sternite 10 in ventral view. Scale bars = $5 \mathrm{~mm}(15-16), 2 \mathrm{~mm}(17), 0.25 \mathrm{~mm}(18-22)$. 
Setouchi-chô, Mt. Eboshi-dake, 3.x.2013, D. Kato (BLKU); 1 , Kagoshima, Amami Island, Yamato-son, Materia Falls, 4.vii.2004, T. Nakamura (SIHU); 5 Â, Kagoshima, Tokunoshima Island, Tokunoshima-chô, Kedoku, Mt. Minada, 30.ix.2013, D. Kato (BLKU). OKINAwa IsLANDs: $4 \hat{\delta} 1$, Okinawa, Okinawa Island, Kunigami-son, Yona, 28.iii.2004, T. Nakamura (SIHU); 1 , Okinawa, Okinawa Island, Nago-shi, Genka, Mt. Ubashi-yama, 12.iii.2017, D. Kato (BLKU). YAEYama IsLands: 1 J, Okinawa, Iriomote Island, Taketomi-chô, Komi, Maira-gawa River, 15.iii.2017, D. Kato (BLKU); 2 ई̊ 1 \&, Okinawa, Ishigaki Island, Ishigaki-shi, Mt. Omoto, 13.xi.2007, T. Nakamura (SIHU); 1 , same data as previous except 26.ix.2013, D. Kato (BLKU); 2 dै, Okinawa, Iriomote Island, Taketomi-chô, Haeminaka to Haemi, 15.iii.2017, D. Kato (BLKU). INDIA: SikкIM: 1 o, Sikkim, Lingtham, 8.viii.1959, T. Schmid (identified by Alexander / USNM).

Redescription. Male. Body length 7.4-9.1 mm. Wing length 8.5-9.6 mm. Body colouration darker and wing marking narrower or smaller in specimens from Yaeyama Islands.

Head yellowish brown to brown with yellowish grey pruinescence; vertex with dark central line; antenna with scape dark brown, pedicel brown; flagellomeres 1-2 orange-yellow, following flagellomeres evenly dark brown; palpus and mouth parts dark brown.

Thorax with mesonotum yellowish brown to brown, darkened at anterior end, this dark area extending posteriorly in short length, lateral sides of prescutum widely dark, anterior inner margin of this dark area sometimes extending posteromedially; pruinescence of mesonotum very weak, indistinct on anterior half in dorsal view; prescutum with four dark areas on posterior third; postsutural area largely darkened at middle, dark area extending to basal area of scutellum; anterior outer edge of scutal lobe with small dark spot; mediotergite slightly darkened with V-shaped lighter area; pleuron yellowish brown, variegated with darker areas and grey pruinescence. Legs with coxae and trochanters yellow to yellowish brown, fore and mid coxae with darker area at middle, hind coxa with dark area on lower half; femora, tibiae and tarsi yellow to yellowish brown; each femur with short weak brown band near tip, 1.0-2.0 times as long as width of femur and sometimes indistinct. Wing (Fig. 17) 3.6-4.2 times as long as wide, greyish subhyaline with brown markings, outlined with dark brown, these darker margins sometimes indistinct on posterior half of wing; markings interrupted transversely at middle of wing in Amami Islands and joining near distal end of cell br in Okinawa and Yaeyama Islands; circular marking enclosing base of Rs with narrow dark seam inside, restricted on base of Rs; markings at distal end of cell sc and on inner and outer ends of cell d solid; cell d with one large subhyaline area at middle; spots at tips of veins near wing tip narrowly connected to adjacent ones; marking at tip of $\mathrm{R}_{2}$ reaching at $\mathrm{R}_{4+5}$; variation of development of wing marking small in same locality. Halter dusky yellow with dark band at base of knob.

Abdomen yellowish brown to brown, each segment with weak pruinescence at caudal margin, strongly widened at lateral sides of tergites; sternites paler, each segment darkened along lateral margins. Male genitalia (Fig. 18) with tergite 9 bearing pair of large and narrow subtriangular median lobes at posterior margin; sternite 9 flattened at caudal margin, without conical tubercle; gonostyli large, about $1 / 2$ length of gonocoxite; interbase (Fig. 19) with rod moderate in length, tip extending beyond tip of aedeagus and ending at about basal $3 / 5$ of gonocoxite, straight on basal 3/4 and curved medially on apical part; base of interbase slightly shorter than rod.

Female. Body length 10.5-11.2 mm. Wing length 8.5$10.4 \mathrm{~mm}$. Generally resembling male except for terminalia.

Ovipositor with sternite 8 (Fig. 20) bearing linear apodeme on lateral side of posterior half; when viewed ventrally, length of sternite 8 excluding hypogynial valve usually slightly shorter than wide; sternite 8 with indistinct dark markings in various areas, marking often indistinct; furca (Fig. 21) vertically long elliptical or tongue-shaped on anterior $4 / 5$, narrowest at fork at basal $1 / 5$, with longitudinal groove extending almost all length of furca; sternite 10 (Fig. 22) roughly squarish, indistinct at anterior margin, with small three projections at posterior margin.

Distribution. Japan (Nansei Islands: Amami Islands; Okinawa Islands; Yaeyama Islands) (Fig. 46), Taiwan, India, and Sri Lanka.

Remarks. The specimens from India have wider femoral bands, about four times as long as width of femur, while 1.0-2.0 times or indistinct in the specimens from Japan. However, based on the structure of the male genitalia, the Japanese specimens are treated as conspecific. This species is very similar to a Taiwanese species, Epiphragma divisum Alexander, 1923 in terms of wing marking and structure of male genitalia, but is distinguished from it by the following characters: each femur with one dark band near tip (without band in E. divisum); brown spots at tips of $\mathrm{M}_{3}$ and $\mathrm{M}_{4}$ very distinct, longer than width of cell $\mathrm{m}_{4}$ (much smaller than half width of cell $\mathrm{m}_{4}$ in E. divisum); marking along $\mathrm{M}_{1}$, $\mathrm{M}_{1+2}$, cord, and tip of CuPsinuous, coarse at outline (gently curved, smooth at outline in E. divisum).

\section{Epiphragma (Epiphragma) subfascipenne Alexander, 1920}

(Figs 23-29, 45)

Epiphragma subfascipennis Alexander, 1920: 10. Type locality: Japan, Honshu, Saitama.

Epiphragma (Epiphragma) subfascipennis: AlEXANDER (1953a: 80); AleXANDER (1953b: 164).

Epiphragma subfascipenne: SAVCHENKo et al. (1992: 215).

Epiphragma (Epiphragma) subfascipenne: OOSTERBROEK (2019).

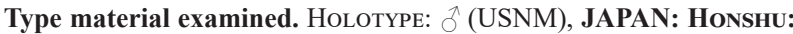
Saitama, 30.v.1919, R. Takahashi.

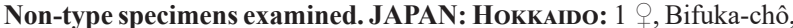
Niupu (MT), 19.vi-17.vii.2010, M. Kuhara \& M. Sueyoshi (SIHU); 3 우, Rumoi-shi (MT), 25.vi-1.vii.2011, Y. Nagayasu (SIHU); 1 , Kuriyama-chô, (MT), 22.vi-12.vii.2006, A. Ueda (SIHU); 1 , Ebetsu-shi, Nopporo (MT), 4.vii.2000, K. Uesugi (SIHU); 1 ふै, Sapporo, Hitsujigaoka (MT), 13-20.vi.2011, K. Konishi (SIHU); 5 o $\bigcirc$, Chitose -shi, Bifue, Kusabue-rindo (MT), 21.vi-8.vii.2012, N. Kuhara (SIHU); 1 \ 2 O , Yûbari-shi, Ôyûbari (MT), 12.vii.2006, collecter not given (SIHU); 3 우, Furano-shi, Nishitappu (MT), 5-26.vi.2009, A. Ueda (SIHU); 1 , Minamifurano-chô, Ikutora (MT), 5-25.vi.2009, A. Ueda (SIHU); 4 †, Ashoro-chô, (MT), 26.vi-17.vii.2008, A. Ueda (SIHU); 2 옹, Shari-chô, Nukamappu-gawa River (MT), 30.vi-13.vii.2001, K. Uesugi (SIHU); 1 q, Teshikaga-chô (MT), 5-26.vi.2008, A. Ueda (SIHU); 7 우, Kushiro-shi, Senpo-ji (MT), 17.vi-23.vii.2002, K. Uesugi (SIHU). Honshu: $1 \curvearrowright 1$, Aomori, Nishimeya-mura, 20.vi.2011, T. Nakamura (SIHU); 1 , Aomori, Nishimeya-mura, Hirasawa-gawa 


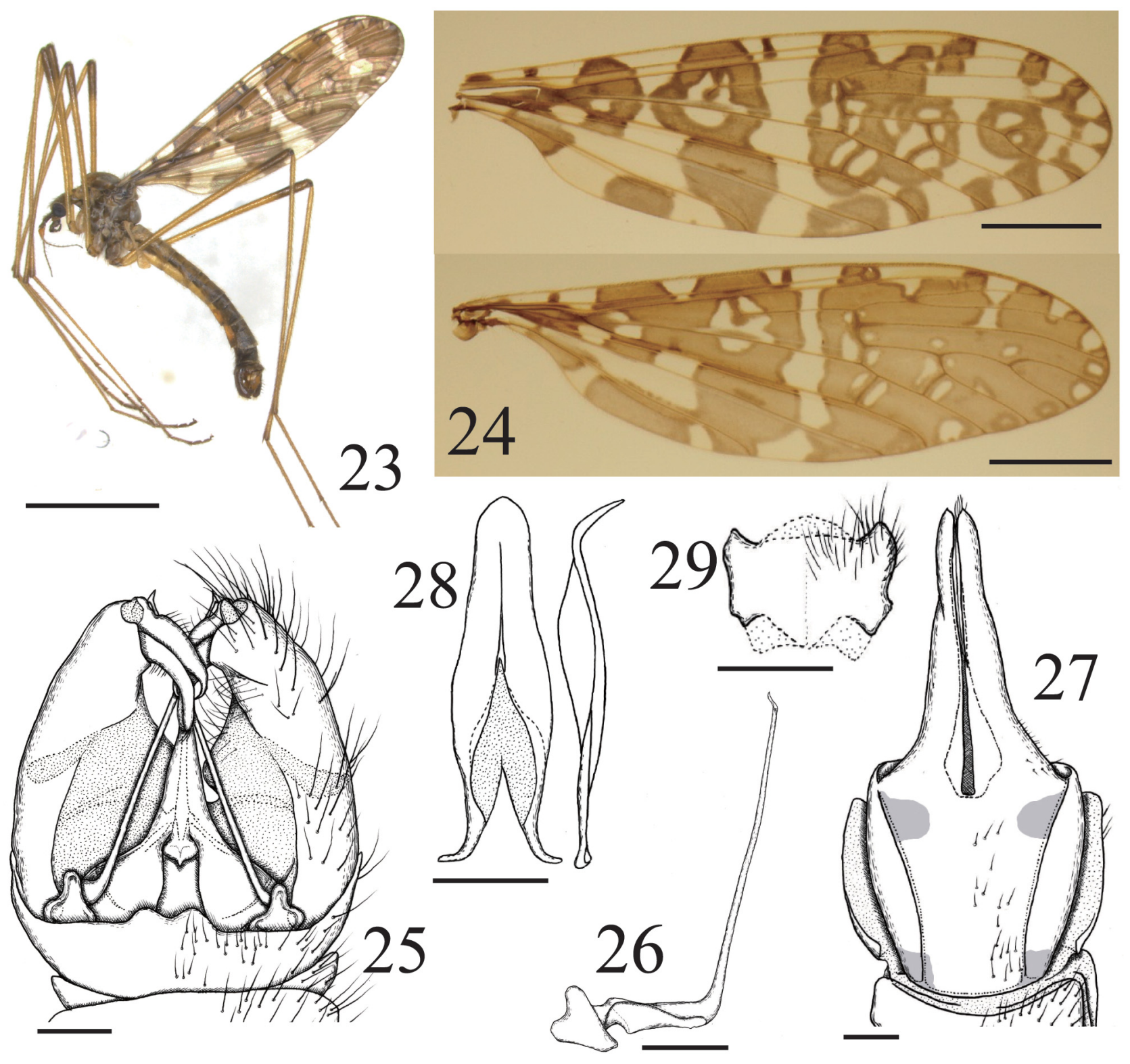

Figs. 23-29. Epiphragma subfascipenne Alexander, 1920. 23 - habitus (male); 24 - wings (upper one with less developed wing marking, lower one with well-developed wing marking); 25 - male genitalia in dorsal view; 26 - interbase in dorsal view; 27 - female abdominal sternite 8 and hypogynial valve in ventral view; 28 - furca in dorsal (left) and lateral (right) views; 29 - female abdominal sternite 10 in ventral view. Scale bars $=5 \mathrm{~mm}(23)$, $2 \mathrm{~mm}(24), 0.25 \mathrm{~mm}(25-29)$.

River, 11.vi.2013, D. Kato (BLKU); 1 \%, Aomori, Towada-shi, Okuse, Tsutanuma Path, 23.v.2014, D. Kato (BLKU); 1 \&, Iwate, Shizukuishi-chô, Koiwai, 6.vii.1993, collector unknown (SIHU); 1 \%, Niigata, Myôkôkôgen-machi, Sasagamine, 28.vi.1999, T. Nakamura (SIHU); 4 of 8 우, Nagano, Kitaaiki-mura, Shiraiwa, 21.vi.2010, T. Nakamura (SIHU); 3 तै 1 \%, Tochigi, Kurobane-machi, Mt. Yamizo-san, 29.v.1994, T. Nakamura (SIHU); 1 , Yamanashi, Ashiyasu-mura, Hirogawara, 14.vi.1996, T. Nakamura (SIHU); 1 \& 1 , Shizuoka, Shizuoka, Mt. Yamabushi-dake, 6.vii.1996, T. Nakamura (SIHU); 11 , Okayama, Maniwa-shi, Hiruzen-Shimotokuyama, 17.v.2015, D. Kato (BLKU); 1 , Hiroshima, Akiôta-chô, Yokogô, 18.v.2015, D. Kato (BLKU). SнгкокU: 1 , Mt. Ishizuchi, 10.vi.1950, Issiki \& Ito (USNM). Kyushu: 6 ô, Kumamoto, Izumi-machi, Shiibagoe, 2.vi.1996, T. Nakamura (SIHU); 1 , same data as previous except 23.v.1997. RUSSIA: FAR EAST: 2 of 2 우, Primorsky Krai, Vladivostok, Chernaya Rechka, 50 m, 4.vi.1992, T. Nakamura (SIHU)

Redescription. Male. Body length $8.0-11.8 \mathrm{~mm}$. Wing length $8.8-13.5 \mathrm{~mm}$.
Head yellowish brown to brown with grey pruinescence; vertex with dark longitudinal central line, anterior half of vertex greyish; antenna with scape and pedicel brown to dark brown, pedicel sometimes slightly yellowish, flagellomeres 1-2 orange-yellow, following flagellomeres slightly darkened toward antennal end; mouth parts including palpus dark brown.

Thorax with mesonotum yellowish brown to brown, darker at lateral margins, with strong grey pruinescence; when viewed dorsally, pruinescence indistinct on anterior and lateral margins of mesonotum; prescutum with four weak darker stripes, central pair more slender than lateral ones, extending to near anterior margin, lateral stripes extending from near level of prescutal pit to scutellum, narrowly interrupted obliquely on scutal lobes; interspace between scutal lobes near posterior ends with pair of brown 
areas; mediotergite brown; pleuron brown to dark brown, mottled with darker areas and strong grey pruinescence. Legs with coxae yellow to dark brown; trochanters yellow; femora, tibiae and tarsomeres 1-2 yellow to yellowish brown, succeeding tarsomeres gradually darkened distally; distal end of each femur with long brown band, 3-5 times as long as width of femur, this band sometimes weakened at extreme tip. Wing (Fig. 24) 3.5-3.8 times as long as wide, greyish subhyaline with brown markings, outlined with dark brown; markings interrupted transversely at basal $1 / 2$ and $3 / 4$ of wing, making three sections of markings, sometimes partly continuous; circular marking enclosing base of Rs with distinct marking inside; both sides of inner and outer ends of cell $d$ with small greyish subhyaline areas; cell d usually with two or sometimes three subhyaline areas; spots at tips of veins near wing tip fused at bases with adjacent ones; variation of development of wing marking large in same locality. Halter entirely light yellow.

Abdomen brown, gradually darkened posteriorly, with strong grey pruinescence, denser along posterior margin of each segment; sternites paler than tergites, darkened along lateral margins. Male genitalia (Fig. 25) with tergite 9 produced into a pair of small rounded median lobes at posterior margin; sternite 9 with conical tubercle directing posteroventrally at center of posterior margin; gonostyli small, about 1/3 length of gonocoxite; interbase (Fig. 26) with rod straight and long, extending far beyond tip of aedeagus and reaching at distal end of gonocoxite, with small barb at apex; base of interbase much shorter than rod.

Female. Body length $11.0-15.0 \mathrm{~mm}$. Wing length $10.3-14.1 \mathrm{~mm}$. Generally resembling male except for terminalia.

Ovipositor with sternite 8 (Fig. 27) with linear apodeme on whole length laterally; when viewed ventrally, sternite 8 excluding hypogynial valve usually slightly longer than wide, with dark markings along linear apodeme, widened at base and around tip, but sometimes indistinct; furca (Fig. 28) blade-shaped, weakly widened near middle, pointed and bent dorsally at apex, ventral surface of furca longitudinally keeled at middle; sternite 10 (Fig. 29) with three projections at anterior and posterior ends, central ones larger and obscure.

Distribution. Japan (Hokkaido; Honshu; Shikoku; Kyushu) (Fig 45) and Russia (Far East).

\section{Epiphragma (Epiphragma) subinsigne Alexander, 1920}

(Figs 30-36, 46)

Epiphragma subinsignis Alexander, 1920: 11. Type locality: Japan, Honshu, Saitama

Epiphragma subfascipennis (misidentification, non Alexander, 1920): EsAKI (1932: 199).

Epiphragma subinsignis: ALEXANDER (1924: 574).

Epiphragma (Epiphragma) subinsignis: AlEXANDER (1953a: 81); AlEXANDER (1953b: 164).

Epiphragma evanescens (misidentification, non Alexander, 1940): TAKAHASHI (1965: 172); NAKAMURA (2008: 289).

Epiphragma subinsigne: SAVCHENKO et al. (1992: 215).

Epiphragma (Epiphragma) subinsigne: OOSTERBRoEK (2019).

Type material examined. HoLotyPe: (USNM), JAPAN: Honshu: Saitama, 29.v.1919, R. Takahashi.
Non-type specimens examined. JAPAN: HoKKaIDo: $39 \circ$, Bifuka-chô, Niupu (MT), 19.vi-17.vii.2010, M. Kuhara \& M. Sueyoshi (SIHU); 1 , Rumoi-shi (MT), 25.vi-1.vii.2011, Y. Nagayasu (SIHU); 2 9 , Kamikawa-chô, Ginsendai (M. T.), 27.vi-18.vii.2008, A. Ueda (SIHU); 2 ^̊, Kuriyama-chô, (M. T.), 22.vi-12.vii.2006, A. Ueda (SIHU); 1 , Ebetsu-shi, Nopporo (MT), 4.vii.2000, K. Uesugi (SIHU); 1 ๆ, Sapporo Hitsujigaoka (MT), 20-27.vii.2010, K. Konishi (SIHU); 1 \%, Chitose-shi, Bifue, Kusabue-rindo (MT), 21.vi-8.vii.2012, N. Kuhara (SIHU); 1 ¿ 2 우, Yûbari-shi, Ôyûbari (MT), 12.vii.2006, collecter not given (SIHU); 1 , Minamifurano-chô, Ikutora (MT), 25.vi-16.vii.2009, A. Ueda (SIHU); 3 ฏ̊, Tomakomai-shi, Hokkaido Univ. Exp. Forest (MT), 2-3. vii.2009, T. Yoshida (SIHU); 2 , Ashoro-chô, Onnetô (MT), 23.vii-30. viii.2002, K. Uesugi (SIHU); 1 đે, Shari-chô, Nukamappu-gawa River (MT), 13.vii-17.x.2001, K. Uesugi (SIHU); 1 ㅇ, Teshikaga-chô (M. T.), 17.vii-7.viii.2008, A. Ueda (SIHU); 3 $\delta 2$ 우, Kushiro-shi, Senpo-ji (MT), 17.vi-23.vii.2002, K. Uesugi (SIHU). Honshu: $2 \hat{\jmath} \hat{\jmath}$, Aomori, Hirosaki-shi, Ichinowatari, 2.viii.2013, D. Kato (BLKU); 1 , Iwate, Takizawa-mura, 4.viii.2013, D. Kato (BLKU); 2 2 20 , Fukushima, Hinoemata-mura, 11.vi.1995, T. Nakamura (SIHU); $5 \lesssim 7$ \ 9 , Niigata, Myôkôkôgen-machi, Sasagamine, 29.vi.1999, T. Nakamura (SIHU); 1 ठ

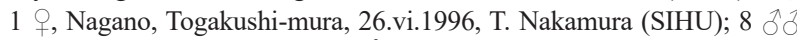
1 , Ishikawa, Hakusan-shi, Mt. Ôarashi-yama, 15.vi.2010, T. Nakamura (SIHU); $1 \hat{\jmath}$, Tochigi, Kanuma-shi, 13.vi.1999, T. Nakamura (SIHU); 1 $\delta$, Ibaraki, Tsukuba-shi, Mt. Hôkyô-san, 12.viii.2011, D. Kato (BLKU); 1 วิ, Tokyo, Hachiôji-shi, Koshino, 4.vi.2011, D. Kato (BLKU); 1 , Kanagawa, Yokosuka-shi, 26.v.2004, Y. Suzuki (SIHU); 5 §̊, Yamanashi, Nirasaki -shi, Sawara-ike Pond, 11.vii.1996, T. Nakamura (SIHU); $5 \lesssim 1$ ○, Shiga, Makino-chô, Mt. Mikuni-san, 6.vi.2012, T. Nakamura(SIHU); 6 § 2 우, Nara, Tenkawa-mura, Dorogawa, 13.vi.2012, T. Nakamura (SIHU); 2 우, Tottori, Yazu-chô, Mt. Ôgino-sen, 17.ix.2014, D. Kato (BLKU); 2 ¡̊ 1 q, Hiroshima, Akiôta-chô, Sandan-kyô, 7.vi.2012, T. Nakamura (SIHU); 1 đ̇, Yamaguchi, Iwakuni-shi, Nishiki-machi-Ôno, Mt. Shôjô-yama, Alt.330 m, 2.ix.2015, D. Kato (BLKU). SнIкокU: 1 \& 1 , Kagawa, Katsuura, Mannô-chô, 16.v.2015, D. Kato (BLKU); 1 q, Ehime, Omogo, 18.vi.1952, T. Ishihara (specimen identified by C. P. Alexander as E. evanescens in 1953 / ELKU); 1 đ̊, Tokushima, Mt. Tsurugi-san, 6.vii.1996, M. Sueyoshi (SIHU). Kyushu: $2 \hat{\jmath} \partial$, Fukuoka, Fukuoka-shi, Nogouchi-keikoku Valley, 16.v.1997, T. Nakamura (SIHU); 1 ô, Fukuoka, Fukuoka-shi, Nishi-ku, Motooka, Kyushu University, south of Ito Campus, 22.iv.2015, D. Kato (BLKU); 1 , same data as previous except 27.iv.2015; $1 \hat{1}$, same data as previous except 4.v.2015; 1 , same data as previous except 14.v.2015; 1 , same data as previous except 25.v.2015; 1 o, same data as previous except 6.vi.2015; 1 , same data as previous except 13.vi.2015;

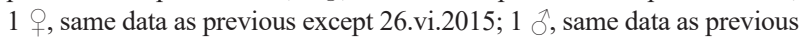
except 1.vii.2015; 1 , same data as previous except 13.vii.2015; 1 , same data as previous except 27.vii.2015; 1 , same data as previous except 11.ix.2015; 1 , same data as previous except 31.x.2015; 1 , Fukuoka, Itoshima-shi, Shimasakurai, Mt. Tenga-dake, 21.vi.2015, D. Kato (BLKU); 1 , same data as previous except 15.viii.2015; 1 of , Fukuoka, Miyakomachi, Saigawa-Hobashira, Notôge Pass, Alt. 740 m, 21.ix.2015, D. Kato (BLKU); 1 , Fukuoka, Fukuoka-shi, Sawara-ku, Itaya, Mt. Sefuri-san, 23.v.2015, D. Kato (BLKU); 1 , same data as previous except 4.vi.2015; 1 , same data as previous except 10.vi.2015; 1 , same data as previous except 3.viii.2015; $1 \lesssim 1$, same data as previous except 5.ix.2015; 1 , Saga, Kanzaki-shi, Sefuri-machi-Haramaki, Mt. Sefuri-san, 17.vi.2015, D. Kato (BLKU); 1 , Saga, Saga-shi, Fuji-machi-Sekiya, Kase-gawa River near Hokuzan Dam, 23.viii.2015, D. Kato (BLKU); 9 $\delta 2$ 우, Ôita, Yufu-shi, Yufuin-chô, 9.vi.2012, T. Nakamura (SIHU); 19 , Ôita, Kokonoe-machi, Tano, 28.vi.2015, D. Kato (BLKU); $11 \lesssim 1$, Kumamoto, Yatsushiro-shi, Shiibagoe, 10.vi.2012, T. Nakamura (SIHU); 1 1 1 +, Miyazaki, Kobayashi-shi, Inoko-dani Valley, 23.v.2004, T. Nakamura (SIHU). TsushIMA ISLAND: $1 \precsim 1$, Nagasaki, Tsushima-shi, Foot of Mt. Mitake, 19.v. 2012, T. Nakamura (SIHU).

Redescription. Male. Body length 7.5-13.0 mm. Wing length 8.0-13.0 $\mathrm{mm}$.

Head yellowish brown to brown with yellowish grey pruinescence; vertex with dark central line; antenna with scape and pedicel dark brown to brown; pedicel sometimes slightly yellowish; flagellomeres 1-2 orange-yellow, sub- 


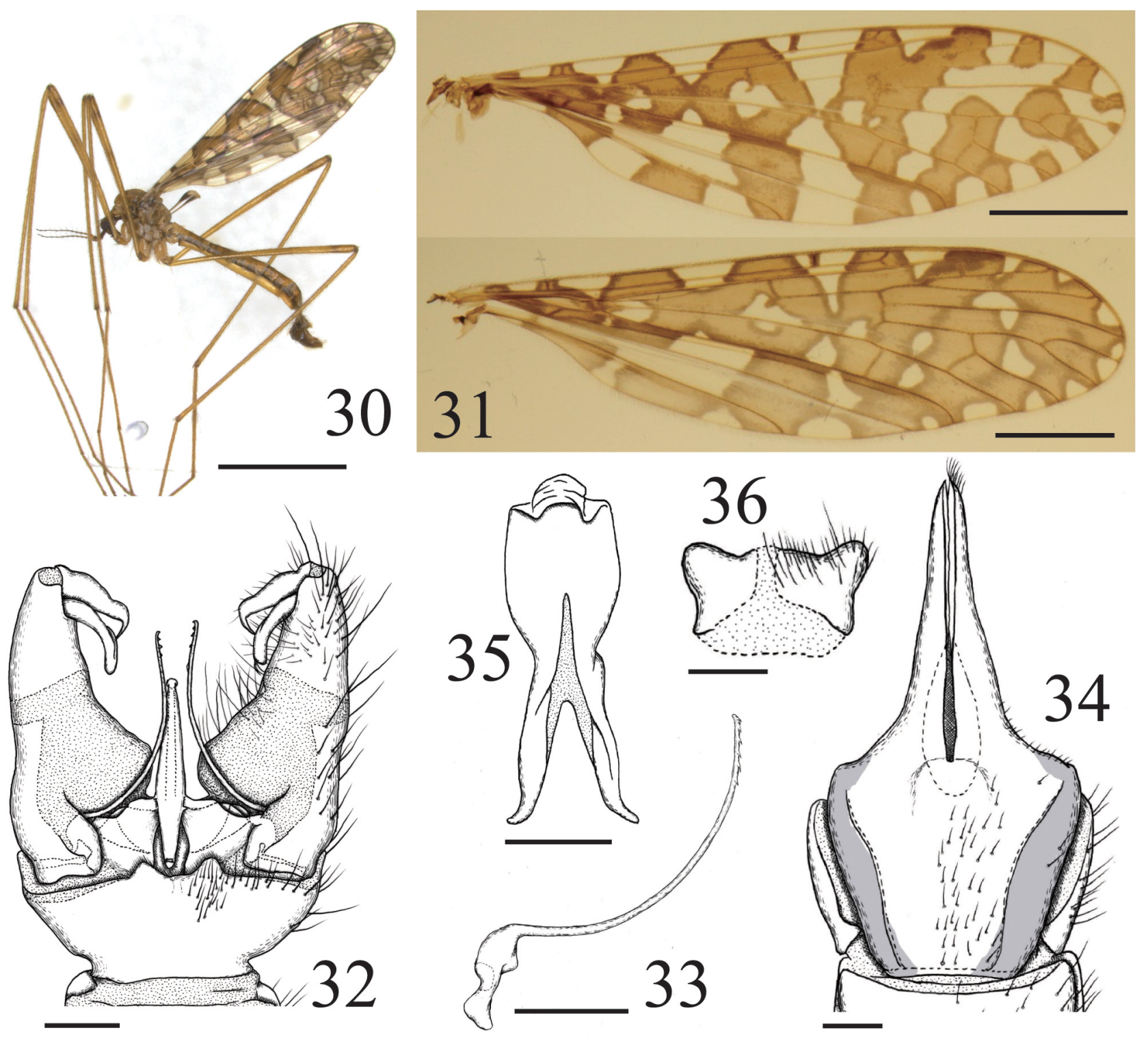

Figs 30-36. Epiphragma subinsigne Alexander, 1920. 30 - habitus (male); 31 - wings (upper one with less developed wing marking, lower one with well-developed wing marking); 32 - male genitalia in dorsal view; 33 - interbase in dorsal view; 34 - female abdominal sternite 8 and hypogynial valve in ventral view; 35 - furca in dorsal view; 36 - female abdominal sternite 10 in ventral view. Scale bars $=5 \mathrm{~mm}(30), 2 \mathrm{~mm}(31), 0.25 \mathrm{~mm}(32-36)$.

sequent flagellomeres slightly darkened toward antennal end; palpus and mouth parts dark brown.

Thorax with mesonotum yellowish brown, lateral and anterior margins darker, with grey pruinescence; pruinescence indistinct on anterior half and lateral sides of prescutum in dorsal view; prescutum with four indistinct darker stripes, central pair more slender, each four stripe extending anteriorly to end at level of middle of prescutum, lateral stripes extending posteriorly to near scutellum, narrowly broken obliquely on scutal lobe; interspace between scutal lobes near posterior end with pair of dark areas, sometimes fused and enlarged; mediotergite yellowish brown; pleuron yellow to yellowish brown, mottled with darker areas and grey pruinescence. Legs with coxae and trochanters pale yellow; femora, tibiae and tarsomeres 1-2 yellow to yellowish brown, sometimes tips of tarsomere 3 to tarsomere 5 darkened; each femur with two brown bands, distal one darker, situated near tip, 1-2 times as long as width of femur, another one at basal 3/4, faint; both or either of bands sometimes indistinct. Wing (Fig. 31) 3.2-3.7 times as long as wide, greyish subhyaline with brown markings, outlined with dark brown; markings interrupted transversely at basal $1 / 2$ of wing, sometimes fused partly with each other; circular marking enclosing near base of Rs without marking inside; markings at distal end of cell sc and both sides of inner and outer ends of cell $\mathrm{d}$ solid; cell $\mathrm{d}$ with one large subhyaline area at middle; spots at tips of veins near wing tip fused or separated at bases with adjacent ones; marking at tip of $\mathrm{R}_{2}$ usually not reaching at $\mathrm{R}_{4+5}$ or rarely joining $\mathrm{R}_{4+5}$ partly; variation of development of wing marking large in same locality. Halter yellow with dark band at base of knob.

Abdomen yellowish brown to brown, with grey pruinescence, denser in posterior margin of each segment; tergites 

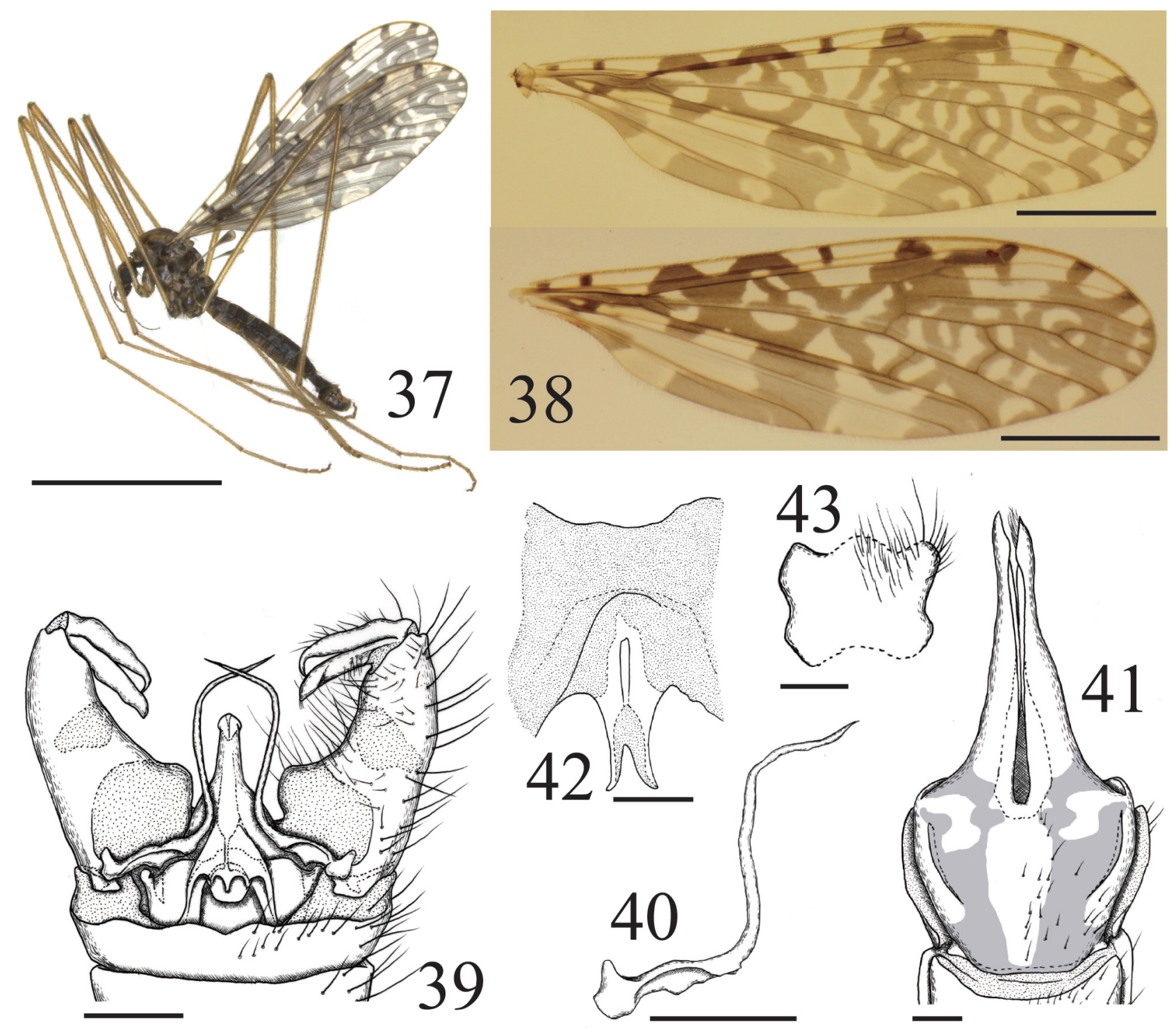

Figs 37-43. Epiphragma trichomerum Alexander, 1955. 37 - habitus (male); 38 - wings (upper one with less developed wing marking, lower one with well-developed wing marking); 39 - male genitalia in dorsal view; 40 - interbase in dorsal view; 41 - female abdominal sternite 8 and hypogynial valve in ventral view; 42 - furca in dorsal view; 43 - female abdominal sternite 10 in ventral view. Scale bars $=5 \mathrm{~mm}(37), 2 \mathrm{~mm}(38), 0.25 \mathrm{~mm}(39-43)$.

1-8 with longitudinal brown line on center; sternites paler than tergites, each segment darkened along lateral margins, sternite 8 entirely darkened. Male genitalia (Fig. 32) with tergite 9 bearing pair of small rounded median lobes at posterior margin; sternite 9 with small conical tubercle at middle before posterior margin; gonostyli small, about $1 / 4-1 / 3$ as long as gonocoxite; interbase (Fig. 33) with rod long and curved in whole length, extending beyond tip of aedeagus and reaching about basal 4/5 of gonocoxite, medial side of rod serrate near tip; base of interbase much shorter than rod.

Female. Body length 9.8-14.1 mm. Wing length 8.5$13.3 \mathrm{~mm}$. Generally resembling male except for terminalia.

Ovipositor with sternite 8 (Fig. 34) bearing linear apodeme on whole length laterally; sternite 8 excluding hypogynial valve usually slightly shorter than wide in ventral view, with dark markings at posterior corners and outside of linear apodeme, these dark areas often indistinct; furca (Fig.
35) narrowest and forked near middle, with anterior half widened, bent dorsally at tip; sternite 10 (Fig. 36) divided at middle by membranous area, posterolateral corners with rounded projections, anterior margin largely emarginated. Distribution. Japan (Hokkaido; Honshu; Shikoku; Kyushu; Tsushima Island) (Fig. 46) and Russia (Far East).

\section{Epiphragma (Epiphragma) trichomerum Alexander, 1955}

(Figs 37-43, 47)

Epiphragma trichomera Alexander, 1955: 286. Type locality: Japan, Shikoku, Ehime, Mt. Saragamine.

Epiphragma subinsignis (misidentification, non Alexander, 1920): ESAKI (1932: 199).

Epiphragma (Epiphragma) trichomera: SAVCHENKo et al. (1992: 215). Epiphragma trichomerum: OOSTERBROEK (2019).

Type material examined. HoLOTYPE: (USNM), JAPAN: SHIKокU: Iyo (Ehime), Mount Saragamine, altitude 1200 meters, 25.vii.1953, Kusunoki. 
Non-type specimens examined. JAPAN: Honshu: $2 \hat{\delta}$, Ishikawa, Hakusan-shi, Chugu, 23.vii.2011, T. Nakamura (SIHU); 1 §, Nagano, Ueda-shi, Sugarairakôgen, 14.vii.2012, D. Kato (BLKU); $2 \hat{\jmath} 2$ 우, Tochigi, Kuriyama-mura, Dorobu, 24.vii.1994, T. Nakamura (SIHU); 1 +, Shimotsuke (Tochigi), Kawamata, 23.vii.1923, T. Esaki (specimen identified by C. P. Alexander as E. subinsigis Alexamder, 1920 in 1923 / ELKU); 5 đ̊̉, Yamanashi, Sutama-chô, Matsutomi Spa, 16.vii.1997, T. Nakamura (SIHU); 1 đે, Yamanashi, Kôshu-shi, Enzankamihagihara, Kaminichikawa-tôge Pass, 8.vii.2014, D. Kato (BLKU). SHгкокU: 1 , , Tokushima, Miyoshi-shi, Higashiiya-Ochiai, near Matsuogawa Dam, Alt. 900 m, 10.viii.2015, D. Kato (BLKU). Kyushu: 12 \% , Fukuoka, Soeda-machi, Mt. Hiko-san, 17.vii.1992, T. Nakamura (SIHU); 1 ô, Fukuoka, Fukuoka-shi, Sawara-ku, Itaya, Mt. Sefuri-san, 3.vii.2015, D. Kato (BLKU); $1 \curvearrowright 2$ 우, same data as previous except 10.vii.2015; 1 $\delta 1$, same data as previous except 24.vii.2015; $1 \precsim 1$, , same data as previous except 30.vii.2015; $1 \hat{\sigma}$, same data as previous except 14.viii.2015; 1 †, Ôita, Yufu-shi, Syonai-chô, Oike Pond, 17.vii.1997, T. Tachi (SIHU); 1 ڤે, Miyazaki, Gokase-cho, Kuraoka, Gokase Ski Area, 28.vi.2015, D. Kato (BLKU).

Redescription. Male. Body length 7.1-9.2 mm. Wing length $8.3-10.0 \mathrm{~mm}$.

Head brown to dark brown with weak grey pruinescence; vertex with dark central line, strongly widened at middle; antenna with scape and pedicel dark brown to brown; flagellomeres 1-2 yellow, following flagellomeres slightly darkened toward antennal end; palpus and mouth parts dark brown.

Thorax with mesonotum yellowish to brown, darkened at anterior margin, lateral sides; area anterodorsal to prescutal pit with weak grey pruinescence; when viewed dorsally, pruinescence indistinct on anterior half of prescutum; prescutum with four darker stripes, sometimes weakened and extending anteriorly to middle of prescutum; postsutural area largely darkened at middle; mediotergite brown with V-shaped lighter area; pleuron dark brown, mottled with darker areas and grey pruinescence. Legs with coxae and trochanters brown, fore coxa with dark area at middle, mid and hind coxae with dark area on lower half; femora, tibiae and tarsi yellow to yellowish brown; each femur with brown band near tip, $0.5-1.5$ times as long as width of femur. Wing (Fig. 38) 3.3-3.6 times as long as wide, greyish subhyaline with dark brown markings of even colouration; markings interrupted transversely at basal $1 / 2$ and/or 3/4 of wing, three sections of markings sometimes partly fused; circular marking enclosing base of Rs with distinct marking inside it; markings at both sides of inner and outer ends of cell $\mathrm{d}$ with small subhyaline areas; cell $\mathrm{d}$ with three subhyaline areas; cell sc often with small subhyaline spot at distal end; spots at tips of veins near wing tip usually fused at bases with adjacent ones; variation of development of wing marking large in same locality. Halter dusky yellow with dark band at base of knob.

Abdomen dark brown, with weak grey pruinescence, denser at posterior margin of each segment; sternites slightly paler than tergites, each segment darkened along lateral margins; sternite 8 dark brown. Male genitalia (Fig. 39) with tergite 9 bearing pair of small rounded median lobes at posterior margin; sternite 9 flattened, without tubercle,
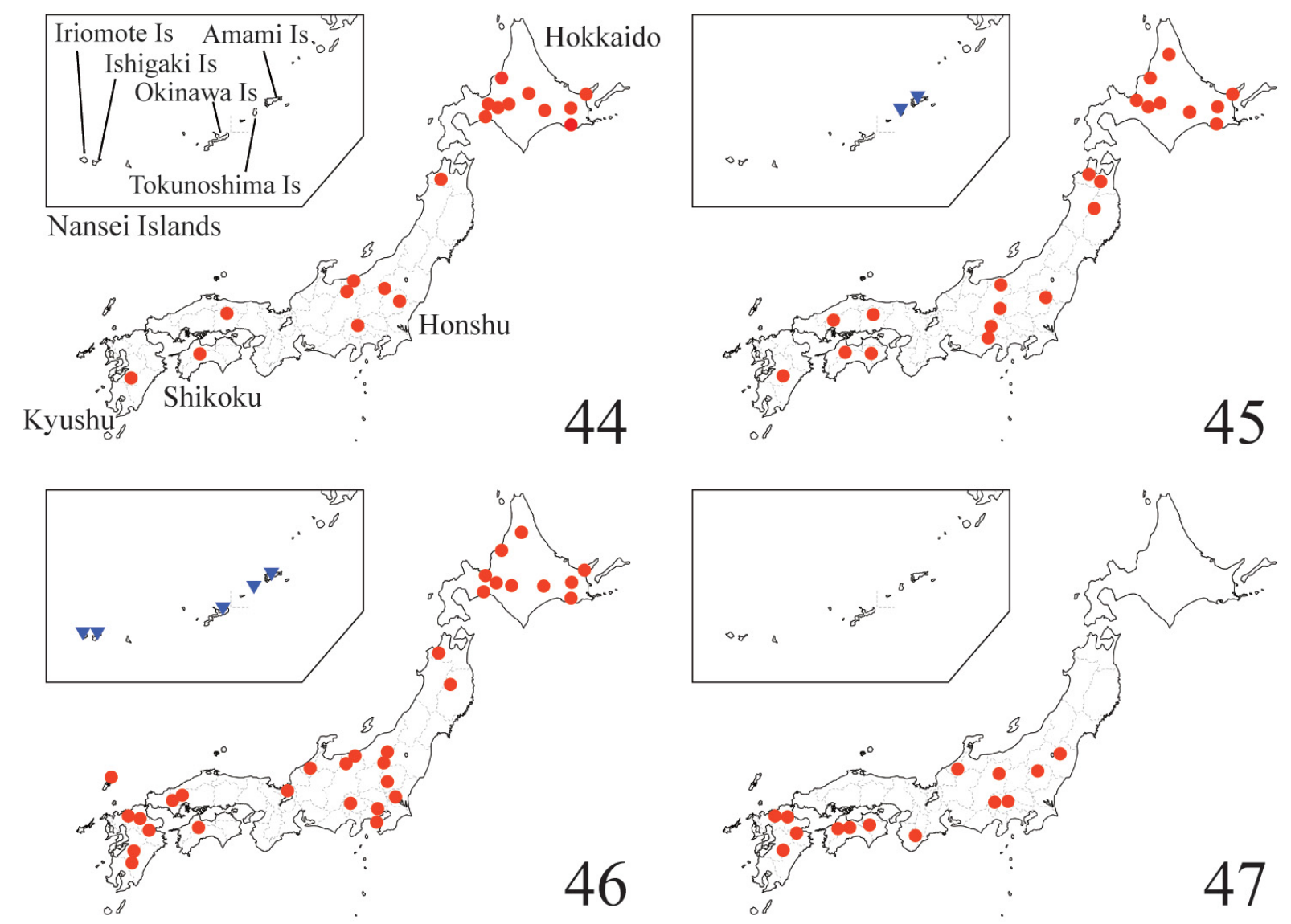

Figs 44-47. Distributions of Epiphragma species in Japan. 44 - E. gracilistylus Alexander, 1933; 45 - E. amamiense sp. nov. (blue) and E. subfascipenne Alexander, 1920 (red); 46 - E. kempi (blue) and E. subinsigne Alexander, 1920 (red); 47 - E. trichomerum Alexander, 1955. 
middle of posterior margin concaved into U-shape; gonostyli large, about $1 / 2$ length of gonocoxite; interbase (Fig. 40) with long and S-shaped rod, extending beyond tip of aedeagus and reaching tip of gonocoxite; base of interbase much shorter than rod.

Female. Body length 8.2-11.1 mm. Wing length 8.0-9.8 $\mathrm{mm}$. Generally resembling male except for terminalia.

Ovipositor with sternite 8 (Fig. 41) with linear apodeme on lateral side of posterior half; when viewed ventrally, length of sternite 8 excluding hypogynial valve usually slightly shorter than wide; sternite 8 with largely pale area near posterior corner, along longitudinal central line, and lateral to linear apodeme, markings sometimes variously weakened; furca (Fig. 42) with anterior part largely widened and membranous, boundary of sclerite indistinct; sternite 10 (Fig. 43) with two low projections at anterior margin and three projections at posterior margin, middle lobes on anterior and posteror sides obscure.

Distribution. Japan (Honshu; Shikoku; Kyushu) (Fig. 47). Remarks. This species is similar to Epiphragma evanescens Alexander, 1940, which was described based only from females, but is differentiated from it by having the furca of ovipositor wide and membranous on anterior end (long rectangular and sclerotized on anterior part in $E$. evanescens). Epiphragma evanescens was described from three female specimens from China (holotype) and Japan (paratypes). As a result of examining these type specimens, it was discovered that the paratypes were the females of E. trichomerum Alexander, 1955. Moreover, we found that Alexander had mistakenly treated a male specimen of E. gracilistylus Alexander, 1933 from Japan as that of E. evanescens. Records of Epiphragma evanescens from Japan are based on misidentifications, and accordingly we remove this species from the Japanese fauna in this paper.

\section{Acknowledgements}

We are especially grateful to T. Yoshida, K. Konishi (Ehime University Museum), H. Makihara (Tsukuba City), R. Matsumoto (Osaka Museum of Natural History), and M. Sueyoshi (Forestry and Forest Products Research Center) for providing valuable specimens. We thank S. Kamitani (Kyushu University), N. Ohbayashi (Ehime University), O. Flint, F. Shockley, and T. Dikow (USNM, Washinton D.C.) for the opportunities to examine specimens in their collections. We are deeply indebted to J. Gelhaus (Drexel University) for critical reading of the manuscript and helping us to examine important specimens in USNM. The first author thanks Y. Ishikawa and H. Yamagishi (Hirosaki University) for their encouragement and support in many ways.

\section{References}

ALEXANDER C. P. 1920: New or little-known crane-flies from Japan (Tipulidae, Diptera). Transactions of the American Entomological Society 46: 1-26.

ALEXANDER C. P. 1923: Undescribed species of Japanese crane-flies (Tipulidae, Diptera). Part III. Annals of the Entomological Society of America 16: 57-76.

ALEXANDER C. P. 1924: New or little-known crane flies from northern Japan (Tipulidae, Diptera). Philippine Journal of Science 24: 531-611.
ALEXANDER C. P. 1933: New or little-known Tipulidae from eastern Asia (Diptera). XV. Philippine Journal of Science 52: 131-166.

ALEXANDER C. P. 1940: Studies on the Tipulidae of China (Diptera). IV. New or little-known crane-flies from Tien-mu-shan, Chekiang (cont.). Lingnan Science Journal 19: 121-132.

ALEXANDER C. P. 1948: New or little-known Tipulidae (Diptera). LXXVIII. Oriental-Australasian species. Annals and Magazine of Natural History, Series 12 14: 256-280.

ALEXANDER C. P. 1953a: The insect fauna of Mt. Ishizuchi and Omogo Valley, Iyo, Japan. The Tipulidae (Diptera). Transactions of the Shikoku Entomological Society 3: 71-83.

ALEXANDER C. P. 1953b: Records and descriptions of Japanese Tipulidae (Diptera). Part II. The crane-flies of Shikoku. II. Philippine Journal of Science 82: 141-179.

ALEXANDER C. P. 1955: Records and descriptions of Japanese Tipulidae (Diptera). Part IV. The crane-flies of Shikoku. IV. Philippine Journal of Science 83: 263-306.

ALEXANDER C. P. 1960: New or little-known Tipulidae (Diptera). CIX. Oriental-Australasian species. Annals and Magazine of Natural History, Series 13 2: 607-625.

ALEXANDER C. P. 1978: New or insufficiently known Australasian crane flies. III. (Tipulidae, Diptera). Studia Entomologica, New Series 20: 99-139.

BRUNETTI E. 1913: Zoological results of the Abor Expedition, 1911-12. Diptera. Records of the Indian Museum 8: 149-190.

CUMMING J. F. \& WOOD D. M. 2017: Adult morphology and terminology. Pp. 89-133. In: KIRK-SPRIGGS A. H. \& SINCLAIR B. J. (eds): Manual of Afrotropical Diptera. Volume 1. Introductory chapters and keys to Diptera families. Suricata 4. South African National Biodiversity Institute, Pretoria, $425 \mathrm{pp}$.

EDWARDS F. W. 1913: New and little-known Diptera Nematocera from Ceylon. Annals and Magazine of Natural History, Series 812: 199-204.

ESAKI T. 1932: Tipulidae. Pp. 172-209. In: UCHIDA S. (ed.): Iconographia Insectorum Japonicorum Editio Prima. Hokuryukan, Tokyo, 2612 pp (in Japanese).

KINOTAK. 2006: Common insects of Sapporo. Hokkaido University Press, Sapporo, 413 pp (in Japanese).

KRIVOSHEINA N. P. 2009: Morphological characterization of the larvae and pupae of Epiphragma (Diptera, Limoniidae). Entomological Review 89: $340-350$.

MACQUART J. 1834. Histoire naturelle des Insectes. Dipteres. Ouvrage accompagne de planches. Tome premier. Librairie Encyclopédique de Roret, Paris, 578 pp.

MAO M. \& YANG D. 2009: New species of the genus Epiphragma Osten Sacken from Yunnan, southwest China (Diptera, Limoniidae). Zootaxa 2121: 44-56.

NAKAMURA T. 2008: Tipulidae, Cylindrotomidae, Limoniidae, and Pedeciidae. Pp. 285-290. In: HIRASHIMA Y. \& MORIMOTO K. (eds.): Iconographia Insectorum Japonicorum Colore Naturali Edita Vol. III. Hokuryukan, Tokyo, 654 pp (in Japanese).

OOSTERBROEK P. 2019: Catalogue of the Craneflies of the World (Diptera, Tipuloidea: Pediciidae, Limoniidae, Cylindrotomidae, Tipulidae). Version 18 Feb 2019 [online]. Available from https://ccw. naturalis.nl/index.php

OSTEN SACKEN C. R. 1860: New genera and species of North American Tipulidae with short palpi, with an attempt at a new classification of the tribe. Proceedings of the Academy of Natural Sciences of Philadelphia 1859: 197-256.

OSTEN SACKEN C. R. 1869: Monographs of the Diptera of North America. Part IV. Smithsonian Miscellaneous Collections 8 (219). Smithsonian Institution, Washington, $345 \mathrm{pp}$.

SAVCHENKO E. N., OOSTERBROEK P. \& STARÝ J. 1992: Families in Volume 1: Limoniidae. Pp. 183-369. In: SOÓS Á., PAPP L. \& OOSTERBROEK P. (eds): Catalogue of Palaearctic Diptera Vol. 1. Trichoceridae-Nymphomyiidae. Hungarian Natural History Museum, Budapest, 520 pp.

TAKAHASHI M. 1965: Tipulidae. Pp. 167-172. In: ASAHINA S., ISHIHARA T. \& YASUMATSU K. (eds): Iconographia Insectorum Japonicorum Colore Naturali Edita Vol. III. Hokuryukan, Tokyo, 358 pp (in Japanese). 
